\title{
CREATIVE DEVELOPMENT OF FUTURE TEACHERS OF HIGHER EDUCATION INSTITUTIONS IN THE PROCESS OF PROFESSIONAL TRAINING
}

\author{
Oksana Filonenko ${ }^{1}$, Olena Habelko ${ }^{2}$ \\ ${ }^{1}$ Doctor of Sciences (Pedagogy), Associate Professor, Volodymyr Vynnychenko Central Ukrainian State \\ Pedagogical University, Kropyvnytskyi, Ukraine, e-mail: oksana.filonenko02@gmail.com, ORCID: \\ https://orcid.org/0000-0003-4453-9887 \\ ${ }^{2}$ Candidate of Pedagogical Sciences, Associate Professor, Volodymyr Vynnychenko Central Ukrainian State \\ Pedagogical University,Kropyvnytskyi,Ukraine, e-mail: lena_gabelko@i.ua, ORCID: \\ https://orcid.org/0000-0003-3769-3616
}

\begin{abstract}
The article reveals the peculiarities of training future teachers in higher education institutions for scientific and pedagogical creativity in terms of master's training. It is established that for the development of creative approach to professional activity of future teachers it is necessary to create conditions in higher education institutions for the development of flexible productive thinking, ability to self-improvement, self-education, reflection of own activity and its results, imagination, improvisation based on knowledge and intuition. For the effective implementation of this process it is necessary to optimize the training of future teachers, to improve the content, methods and forms of educational activities in higher education institutions. It was determined that mastering research activities is the first and main goal of training specialists of master's degree. The research activity of a future teacher is an important condition for the development of a creative, proactive specialist with a focus on constant knowledge, the desire to determine the essence of any phenomenon, finding the best means of solving professional problems, constant experimentation, self-analysis and self-evaluation. Participation in research develops in future teachers a reflection of their own life and professional needs and interests, which is carried out in the process of professionally oriented research tasks, which provides objectivity and forms a critical and constructive attitude to themselves, helps to realize their compliance with the profession and scientific -research activities, when the future teacher acquires the skills of independent thinking, finds meaning and ways to improve themselves in this activity. Research activity satisfies the needs of the future teacher in achieving success, self-knowledge, selfrealization, in understanding the content of their activities, in a systematic vision of their prospects. Objective reality encourages us to pay more attention to the development of research skills in future teachers of higher education institutions.
\end{abstract}

Keywords: professional training, future teacher, institution of higher education, creativity, pedagogical creativity, research activity.

JEL Classification: I 24, I 29

Formulas: 0; fig.: 0; tabl.: 0; bibl.: 12

Introduction. Professional training of teachers for higher education institutions, able to quickly and effectively adapt to the changing conditions of society today is a guarantee of the quality of higher education, an important factor in its development.

Preparation of future teachers of higher education institutions for professional activity, which is inherently creative, allows to expand the range of professional interests of specialists, gives the opportunity to meaningfully implement and test innovative proposals, helps to involve teachers in internal restructuring of the educational process, which can guarantee his steady self-improvement, readiness to the adoption of innovations by teachers. 
In a number of educational documents: Laws of Ukraine "On Higher Education" (2014) [4], "On Education" (2017) [5] and others, emphasis is placed on the formation of the intellectual potential of the nation and the comprehensive development of the individual as the highest value of society. As a result, the role of the teacher of higher education institutions is changing, his/her activity is to provide a universal mechanism for the systematic functioning of professional thinking, mastering which will help future teachers in any situation to bring quality to the issue, attract attention, interest, show inconsistencies and resolve contradictions, to substantiate the correctness of problem solving and to take concrete actions in practice, predicting their consequences, and to reveal the dynamics of feelings, emotions, motives, needs, goals, studying the direction of personality development.

Therefore, the formation of scientific and pedagogical knowledge, methods of action and development of attitudes to innovation in future teachers should be considered as a strategic task. V. Sukhomlynskyi, an outstanding pedagogue, expressed his opinion on the need to combine the functions of a teacher with the functions of a teacher: "If you want pedagogical work to bring joy to the teacher, so that everyday lessons do not become a boring monotonous necessity, lead each teacher on a happy path of research ... Become a master of pedagogical work, most likely one who has felt the researcher ..." [11, p. 68].

The urgency of the problem of training future teachers for scientific and pedagogical creativity in the conditions of master's training is determined by various factors. Solving it both theoretically and practically will significantly increase the level and quality of professional training, ensure the formation and development of masters of sustainable interests in research and teaching, as well as mastering certain skills and abilities of research. This, in turn, will provide conditions for improving the efficiency of the educational process in a modern higher education institution, where the main focus is on the latest technologies of student learning, personality-oriented approach in the pedagogical process, creative solution of didactic, developmental and educational tasks.

Thus, democratic and humanistic processes in Ukraine determine pedagogical methods and styles associated with the personality-oriented, creative and innovative activities of the future teacher of higher education. A socially significant direction of subject-methodical training is the updating on a humanistic basis of its purpose, content, forms, methods, techniques and the formation of an innovative style of activity of the future teacher.

Literature review. The analysis of psychological and pedagogical literature shows that the professional training of the future teacher of higher education, the development of his professionally significant qualities is given due attention. In the scientific aspect, the system of teacher training for higher education institutions was considered in the context of creating a domestic system of higher education (V. Andrushchenko, I. Bekh, A. Bohush, I. Zyazyun, M. Stepko, etc.), the formation of teacher competence in the master's program. (O. Gura), development of creative potential of the future teacher of higher school (R. Tsokur), preparation of undergraduates for research activity (G. Matushansky, Y. Solyannikov), increase of 
efficiency of preparation of students of a magistracy (V. Bereka, S. Vitvytska, V. Bondar, O. Moroz, Z. Slipkan), etc. However, the problems of quality of training, its tasks and ways to achieve the required level of readiness of future masters of higher education institutions for scientific and pedagogical creativity still need scientific development.

Aims. The purpose of the article is to reveal the peculiarities of training future teachers of higher education institutions for scientific and pedagogical creativity in the conditions of master's training.

Methods. General scientific research methods, empirical (description) and theoretical (analysis, generalization, explanation, etc.) were used while writing the article.

Results. The concept of "pedagogical creativity" is one of the central concepts of psychological and pedagogical science. Pedagogical creativity, as noted by A. Markov, is a search and solution of something new, previously unknown: for himself (discovery by the teacher of various non-standard ways of solving pedagogical problems) or for himself and for others (use of innovative approaches and techniques) $[8$, p. 8]. Its prerequisite is the flexibility of human thinking, which is manifested in the ability of the individual to a multifaceted vision of the world.

V. Kan-Kalik and M. Nikandrov, considering the creative essence of pedagogical activity, note: "the originality of pedagogical creativity is that the creative nature is not only the act of solving a pedagogical problem, but also the process of implementing this decision in communication with children" [ 7, p. 56]. According to V. Sukhomlinsky, harmonious, comprehensive development, education, spiritual wealth, moral purity - all these a person achieves when, along with intellectual, moral, aesthetic culture, he reaches a high degree of culture of labor, labor creativity [9].

The process of development of pedagogical creativity is complex and multifactorial. It depends on a number of complementary conditions:

- pedagogical competence;

- desire for creative search;

- possession of pedagogical equipment;

- pedagogical experience;

- acting skills;

- imagination and intuition;

- observation;

- flexibility of thinking;

- psychological literacy, etc. [7, p. 3].

If the system of professional training of teachers, despite all the new developments and changes, is provided by higher pedagogical educational institutions of the IV level of accreditation, the system of teacher training of higher educational institutions does not meet modern needs of society: most scientific and pedagogical staff of higher education lack psychological and pedagogical education, which largely determines the success of all functions of pedagogical activity, - says O. Hura [3, p. $3]$. 
The analysis of modern scientific research has shown that for the development of a creative approach to professional activity it is necessary to create conditions for the development of flexible productive thinking, ability to self-improvement, selfeducation, reflection of own activity and its results, imagination, improvisation based on knowledge and intuition. This will allow you to generate a variety of original ideas, solve non-trivial, complex problems, operate with conflicting information. For the effective implementation of this process it is necessary to optimize the training of teachers, improve the content, methods and forms of educational activities in higher education institutions.

According to S. Vitvytska, the main content of the higher education institution is the formation of an innovative educational environment, which involves: changing the organization and content of education in order to integrate into the world educational space; staff optimization; comprehensive improvement of professional skills of teachers. through mastering innovative and experimental activities [1].

E. Zeyer emphasizes that the professional development of the teacher's personality is influenced by the development of his creative potential. The imperfection of the system of stimulating the creative work of the teacher, the inefficiency of functioning, generalization, dissemination of advanced pedagogical experience and creative discoveries of teachers-innovators negatively affect the selfrealization of the future teacher who will work in higher education [6].

It should be noted that mastering research activities is the first and main goal of training specialists in the master's degree. The essence of research as a specific type of human activity is characterized by the factor of "discovery" of new knowledge, which arises on the basis of previous knowledge and human experience, much attention in this aspect is paid to the process of cognition. student and teacher activity "[10, p. 11]. It is also a means of training a new type of specialist. We believe that its achievement will strengthen the role of scientific activity in the educational process; to ensure the joint participation of undergraduates and teachers in the implementation of specific research work; create conditions for creative scientific growth of undergraduates; to stimulate in them development of steady professional interest in scientific work; integration of educational and research activities of students; intensification and individualization of the educational process.

Most scholars associate the term "research" with the term "creativity". Thus, V. Lazarev and N. Stavrinova say the following about the connection between creativity and research: creative activity turns into research every time a specialist, summarizing his experience, implementing the experience of his colleagues or new technologies, consciously uses such research methods that give opportunity to obtain objective data on the results of his creative work [8, p. 51].

Student creativity is one of the most important conditions for becoming a future specialist. A student with a high level of creative development feels an inner need for research. It should be noted that creativity is based on two interrelated principles: personal and activity, which can develop only through each other. Therefore, creativity can be considered as an intrinsic essential property of the individual, which 
is manifested both in activity in general and in specific forms. Such a specific form of activity is human research.

According to S. Vitvytska, comprehensive preparation of undergraduate students for research and scientific-pedagogical activities involves:

- mastering the methods, techniques and procedures of scientific work and teaching;

- acquisition of skills of organization of scientific and pedagogical activity;

- mastering computer and other technical means used in research activities;

- gaining experience in preparing publications and educational and methodological developments [2, p. 45].

Shifting the emphasis from teaching to the organization of student learning as an independent systematic self-educational activity, which is only accompanied and supported by the teacher, becomes one of the most important guidelines for substantiating the content of training highly qualified teachers for higher pedagogical school, defining its strategic goals and guidelines.

S. Vitvytska emphasizes that the main value of master's training is that it allows to prepare specialists who already have certain achievements for admission to graduate school in the form of publications, experience of participation in scientific discussions at conferences and seminars. In view of this, master's studies should be aimed at training a researcher who is able not only to solve scientific problems in a specific professional and educational field, but also capable of reflection, creativity and self-knowledge.

S. Vitvytska distinguishes between teaching and research activities of undergraduates. According to her, research activities of undergraduates are implemented mainly in the educational process in the performance of educational tasks, research - in the performance of qualifying work, which is considered an independent research that contains a set of results and scientific provisions put forward by the undergraduate for public defense. But both in teaching and in mastering science, undergraduates must rely on research [2, p. 50].

The preparation of students for scientific and pedagogical creativity should be purposeful systemic. In the practice of higher education institutions, students are widely used tasks for independent work, which include the compilation of: summary tables; structural block diagrams of the lecture; crossword puzzles on the topic; tests on the topic (single, multiple, alternative and orderly choice); a list of definitions of key concepts of the course with reference to sources; annotation of articles (5-6 on one topic of the course), books or separate sections that are closely related to the topic; writing essays and reports on topics identified by the teacher; various group tasks that involve solving or preparing problem situations; preparation and defense of qualifying works.

As one of the most important objective conditions for the development of pedagogical creativity, scientists consider the influence of socio-cultural, pedagogical reality, a specific cultural and historical context in which the teacher creates in a certain period of time. Other objective conditions include: a positive emotional psychological climate in the team; level of development of scientific knowledge in 
psychological-pedagogical and special spheres; availability of adequate means of training and education; scientific substantiation of methodical recommendations and installations, material and technical equipment of pedagogical process, etc [12].

We support the opinion of T. Shcherbakova that a significant potential in the development of creativity of future teachers has an aesthetically competently organized environment of higher education, which includes such components as the exterior of the building, interior, aesthetic organization of the educational process, aesthetic cycle subjects [12, p. 22].

Discussion. To develop a creative approach to professional activity in future teachers it is necessary to create conditions in the university for the development of flexible productive thinking, ability to self-improvement, self-education, reflection on their own activities and its results, imagination, improvisation based on knowledge and intuition. For the effective implementation of this process it is necessary to optimize the training of future teachers, improve the content, methods and forms of educational activities in higher education institutions.

The research activity of a future teacher is an important condition for the development of a creative, proactive specialist with a focus on constant knowledge, the desire to determine the essence of any phenomenon, finding the best means of solving professional problems, constant experimentation, self-analysis and selfevaluation. Participation in research develops in future teachers a reflection of their own life and professional needs and interests, which is carried out in the process of professionally oriented research tasks, which provides objectivity and forms a critical and constructive attitude to themselves, helps to realize their compliance with the profession and scientific -research activities, when the future teacher acquires the skills of independent thinking, finds meaning and ways to improve themselves in this activity. Research activity satisfies the needs of the future teacher in achieving success, self-knowledge, self-realization, in understanding the content of their activities, in a systematic vision of their prospects.

Conclusions. Thus, in the educational environment of a higher education institution there should be a place of active search, realization of abilities and interests of students, accumulation of personal creative experience. All this will promote the development of creative abilities of students, which they will be able to implement in further teaching activities. We see prospects for further research in the selection of pedagogical conditions that contribute to the formation of the readiness of future teachers of higher education institutions for scientific and pedagogical creativity.

Author contributions. The authors contributed equally.

Disclosure statement. The authors do not have any conflict of interest. References:

1. Vitvyts'ka, S. S. (2005), Praktykum z pedahohiky vyshchoyi shkoly: navch. Posibnyk [Workshop on Pedagogics of Higher Education], K.: Tsentr navchal'noyi literatury. [in Ukraine]

2. Vitvyts'ka, S. S. (2004), Suchasni tekhnolohiyi pidhotovky mahistriv v umovakh stupenevoyi pedahohichnoyi osvity [Modern technologies of masters training under conditions of advanced pedagogical education], Visnyk Kyyivs'koho mizhnarodnoho universytetu, K.: KMU, Seriya: Pedahohichni nauky. Vyp. 5. [in Ukraine] 
3. Hura, O. I. (2008), Teoretyko-metodolohichni osnovy formuvannya psykholoho-pedahohichnoyi kompetentnosti vykladacha vyshchoho navchal'noho zakladu $v$ umovakh mahistratury [Theoretical and methodological foundations of formation of psychological and pedagogical competence of a teacher of a higher educational establishment in the conditions of a magistracy], Avtoref. dys. na zdobuttya nauk. stupenya d-ra ped. nauk: spets. 13.00.04 "Teoriya i metodyka profesiynoyi osvity". [in Ukraine]

4. Zakon Ukrayiny «Pro vyshchu osvitu» [Law of Ukraine "On Higher Education"] vid 01.07.2014 № 1556VII / Baza danykh «Zakonodavstvo Ukrayiny» / Verkhovna Rada Ukrayiny. URL: http://zakon3.rada.gov.ua/laws/show/en/1556-18 [in Ukraine]

5. Zakon Ukrayiny «Pro osvitu» [Law of Ukraine "On Education"] vid 05.09.2017 № 38-39 / Baza danykh «Zakonodavstvo Ukrayiny» / Verkhovna Rada Ukrayiny. URL: http://zakon3.rada.gov.ua/laws/show/2145$\underline{19}$ [in Ukraine]

6. Zeyer, E. F. (1988), Professional'noye stanovleniye lichnosti inzhenera-pedagoga [Professional formation of the personality of an engineer-teacher], Sverdlovsk: I zd-vo Ural. un-ta. [in Russian].

7. Kan-Kalik, V. A., Nikandrov, N. D. (2003), Pedagogicheskoye tvorchestvo [Pedagogical creativity], M. [in Russian].

8. Lazarev, V.S., Stavrinova, N. N. (2006), Kriterii $i$ urovni gotovnosti budushchego pedagoga $k$ issledovatel'skoy deyatel'nosti [Criteria and levels of readiness of the future teacher for research activities], Pedagogika, № 2. [in Russian].

9. Markova, A. K. (2003), Psikhologiya truda uchitelya [The Psychology of Labor of a Teacher], M.: Prosveshche-niye. [in Russian].

10. Passov, Ye. I. (2002), Kul'turosoobraznaya model' professional'noy podgotovki uchitelya: filosofiya, soderzhaniye, realizatsiya [Cultural model of professional training of a teacher: philosophy, content, implementation], Ínozemní movi, № 4. [in Russian].

11. Sukhomlyns'kyy, V O. (1971), Metodyka vykhovannya kolektyvu [Method of education of the collective], K.: Rad. Shkola. [in Ukraine]

12. Shcherbakova, T. N. (2013), Tvorchestvo v deyatel'nosti sovremennogo pedagoga [Creative Work in the Activities of a Modern Teacher], Aktual'nyye voprosy sovremennoy pedagogiki: materialy IV mezhdunarodnoy na-uchnoy konferentsii, (g. Ufa, noyabr' 2013 g.) Ufa: Leto. [in Russian]. 